\title{
INTRODUCTION TO SYMPOSIUM ON THE THIRD RESTATEMENT OF CONFLICT OF LAWS
}

\author{
Carlos M. Vázquez*
}

The American Law Institute (ALI) has recently embarked on the project of elaborating a new Restatement of Conflict of Laws. Its first two Restatements on this subject have been enormously influential. The ALI began its work on the First Restatement in 1923, naming Joseph Beale of the Harvard Law School as its Reporter. Adopted in 1934, the First Restatement reflected the highly territorialist approach to the conflict of laws that had long prevailed in this country. Even before the First Restatement's adoption, the First Restatement's territorialist approach, and the "vested rights" theory on which it was based, was subjected to intense scholarly criticism. ${ }^{1}$ Nevertheless, the First Restatement's approach continued to prevail in the United States until the New York Court of Appeals initiated a "choice-of-law revolution" in the early 1960's with its decision in Babcock v. Jackson. ${ }^{2}$ Although most states have departed from the First Restatement's approach, the First Restatement retains its adherents. Ten states continue to follow the First Restatement for tort cases and twelve states for contract cases. ${ }^{3}$

The ALI initiated its revision of the Restatement of Conflicts in 1952, naming Willis L.M. Reese of Columbia Law School as its chief reporter. ${ }^{4}$ The Second Restatement of Conflicts was finally adopted in 1974. The Second Restatement, too, has been criticized by scholars, primarily for providing insufficient guidance to the courts. Despite its indeterminacy, or perhaps because of it, the Second Restatement has proved to be popular with judges. It is currently followed by twenty-four states for tort cases and by twenty-three states for contracts cases. ${ }^{5}$

AJIL Unbound is pleased to present this symposium on the recently initiated project to elaborate a Third Restatement of Conflict of Laws. The symposium features contributions from two of the Restatement's Reporters and two of its Advisers.

In "What a Third Restatement of Conflicts Can Do," the Third Restatement's chief Reporter, Kermit Roosevelt III, along with co-author Bethan Jones, offer a critique of the first two Restatements and express their hope that the Third Restatement will "bring greater predictability to choice of law by providing more

* Professor of Law, Georgetown University Law Center.

Originally published online 05 October 2016.

1 See, e.g., David Cavers, A Critique of the Choice-of-Law Problem, 47 Harv. L. Rev. 173 (1933); Walter W. Cook, The Logical and Legal Bases of Conflict of Laws, 33 YALE L.J. 457 (1924); Ernest G. Lorenzen, Territoriality, Public Policy and the Conflict of Laws, 33 YALE L.J. 736 (1924).

2 Babcock v. Jackson, 191 N.E.2d 279, 286 (N.Y. 1963). See Harold Korn, The Choice of Law Revolution: A Critique, 83 COLUM. L. REv. 772 (1983).

3 See Symeon C. Symeonides, Choice of Law in the American Courts in 2015: Twenty-Ninth Annual Survey, 63 AM. J. COMP. L. 221,292 (2016).

4 See Willis L.M. Reese, Conflict of Laws and the Restatement Second, 28 L. \& ConTEMP. Probs. 679, 680 (1963).

5 See Symeonides, supra note 3, at 292. 
determinate rules, rather than open-ended balancing." "They also discuss the "two-step" process that, in their view, offers the most promising framework for the elaboration of such rules. ${ }^{7}$

The thesis of Lea Brilmayer's contribution to this symposium is aptly captured in its title, "What I Like Most About the Restatement (Second) of Conflicts, and Why It Should not Be Thrown out with the Bathwater." Brilmayer, an Adviser to the Third Restatement, urges retention of the Second Restatement's "aggregate contacts" approach to choice of law and offers some preliminary thoughts on how such an approach might be refined in the Third Restatement. ${ }^{9}$

The third contribution to the symposium is from Christopher Whytock, who is an Associate Reporter of the Third Restatement. In "Toward a New Dialogue Between Conflict of Laws," Whytock offers reflections of the relationship between conflict of laws and international law and explores how international law scholarship might contribute to the Third Restatement project. ${ }^{10} \mathrm{He}$ also discusses the relation between the Third Restatement project and the ALI's ongoing project to elaborate a new Restatement of Foreign Relations Law (to which Whytock is also an Adviser).

The final contribution is by Ralf Michaels, an Adviser to the Third Restatement. ${ }^{11}$ In his wide-ranging essay, Michaels explains why, in his view, the rules and principles in the Third Restatement should be formulated with international disputes in mind. He discusses, in particular, five concrete sets of issues as to which an international or comparative focus would be especially fruitful. Finally, Michaels raises some questions about the appropriateness for international disputes of the methodological approach that undergirds the current draft of the Third Restatement, namely, the "two-step" version of governmental interest analysis. ${ }^{12}$ (Brilmayer, too, expresses some skepticism about the "two-step" approach, and Roosevelt and Jones respond. ${ }^{13}$ )

AJIL Unbound is pleased to have initiated this exchange about the directions the Third Restatement of Conflict of Laws might take. We and the authors hope that the conversation will continue in other fora.

${ }^{6}$ Kermit Roosevelt III \& Bethan Jones, What a Third Restatement of Conflict of Laws Can Do, 110 AJIL Unbound 139, 141 (2016).

${ }^{7}$ Id. at 142 .

${ }^{8}$ Lea Brilmayer, What I Like Most About the Restatement (Second) of Conflicts and Why It Should not be Thrown out with the Bathwater, 110 AJIL UNBOUND 144 (2016).

${ }^{9}$ Id. at 145.

${ }^{10}$ Christopher A. Whytock, Toward a New Dialogue Between Conflict of Laws and International Law, 110 AJIL UnBOUND 150 (2016).

${ }^{11}$ Ralf Michaels, The Conflicts Restatement and the World, 110 AJIL Unbound 155 (2016).

${ }^{12} I d$. at 158.

${ }_{13}$ Brilmayer, supra note 8, at 144; Roosevelt \& Jones, supra note 6, at 143, n. 19. 